\title{
Perceptions from Beyond: Some Observations on Non-Roman Assessments of the Roman Empire from the Great Eastern Trade Routes
}

\author{
Anne Kolb and Michael A. Speidel
}

Centuries of continuous warfare and successful expansion turned the Roman Empire into the single dominant power in the Mediterranean basin. Yet, although Roman warfare never fully came to an end, the countryside and the two to three thousand cities of the Empire in Italy and the provinces experienced many uninterrupted decades of peaceful prosperity from the beginning of the imperial era onwards. This prosperous Roman world, the orbis Romanus, owed much of its success to an extensive network of communication lines by land and sea, through which it was interconnected and accessible. The development of the imperial transport and communication infrastructure reflects both the pragmatic and systematic approaches of the Romans: Building on existing local lines of communication, the Romans took over, expanded or constructed new roads in the deployment zones and in the countries they had conquered. Thereby, they systematically and consistently linked newly acquired territory with the center. In a next step following the establishment of peace-especially under the Empire-, Roman building programs improved and further expanded traffic connections in the subjected areas incorporated into the road network in order to penetrate the territory of the empire. All elements of this network by land and sea made up an estimated length of around 500.000 kilometers. ${ }^{1}$

Nevertheless, even today this network is often thought of as a closed system, covering only the Roman world. But that was clearly not the case. Travel and commerce were by no means hindered by the confines of the Roman

1 See recently Anne Kolb, "The conception and practice of Roman rule: the example of transport infrastructure," Geographia Antiqua 20/21 (2011/12), 53-69 and A. Kolb, "Erfassung und Vermessung der Welt bei den Römern," in Vermessung der Oikumene, ed. Michael Rathmann and Klaus Geuss (Berlin, 2013) 107-118. A slightly augmented version of this paper will be published in the Chinese Journal of Ancient Civilizations, vol. 30 (2016). 
the empire. Even the great military barriers in Britain, on the German frontier and in North Africa were permeable. Roman traffic ways connected to lines of communication into territories well beyond the empire. In most cases, these routes had been in use for centuries before the Roman conquest. They led by land or sea to the north, south or east, and ultimately connected the Mediterranean with the countries on the North and Baltic Seas, Sub-Saharan Africa, Central Asia, India and China. Since the conquests of Alexander the Great and the 'discovery' of the Monsoon winds in the second century CE, trade relations between the Mediterranean world and the countries of the Far East intensified, ${ }^{2}$ and India and China were firmly integrated into the Western concept of the inhabited world, the 'oikumene'.

The famous medieval copy of an illustrated imperial Roman 'road map' (itinerarium) known as the 'Tabula Peutingeriana' with its depiction of the entire Roman road system from Britannia to the east provides a graphic illustration of this notion. For it shows how, in the east, the network of Roman roads seamlessly continues into non-Roman territories. Moreover, the last sheet of this remarkable document includes, for instance, references to Sera Maior (presumably China), the Ganges river ( $f$ l. Ganges), and the well known ancient seaport of Muziris with its templ(um) Augusti on the Malabar coast in south west India. ${ }^{3}$ The 'Tabula Peutingeriana' therefore displays a network of

2 See e.g. Raphaela Drexhage, Untersuchungen zum römischen Osthandel (Bonn, 1988). Gary Keith Young, Rome's Eastern Trade. International commerce and imperial policy, ${ }^{1} B C-A D$ 305 (London, 2001). Kai Ruffing, "Wege in den Osten: Die Routen des römischen Ost- und Südhandels (1.-2. Jh.)," in Zu Wasser und zu Land. Verkehrswege in der antiken Welt, ed. E. Olshausen and H. Sonnabend, Stuttgarter Kolloquium zur Historischen Geographie des Altertums 7 (Stuttgart, 2002), 360-378. Steven E. Sidebotham, Berenike and the ancient maritime spice route (Berkeley, 2011). Michael A. Speidel, "Wars, Trade and Treaties. New, revised, and neglected sources for political, diplomatic, and military aspects of imperial Rome's relations with India and the Red Sea basin, from Augustus to Diocletian," in Imperial Rome, Indian Ocean Regions and Muziris: Recent Researches and New Perspectives on Maritime trade, Proceedings of the international Seminar held at Irinjalakuda, Kerala, India 8-12 September 2013, ed. K.S. Mathew (New Dehli, 2015), 83-128.

3 Tab. Peut. 11,5. For Muziris see also Plin., NH 6,26,104. Periplus Maris Erythraei (= PME) 57. Ptol., Geogr. 4,5,14-15. Lukian, Quomodo historia conscripta sit, 31. For the templum Augusti see Michael A. Speidel, "Der Augustustempel bei Musiris. Zur Tabula Peutingeriana und zum Kaiserkult ausserhalb des Reiches”, in: 'Kaiserkult in den Provinzen des Römischen Reiches Organisation, Kommunikation und Repräsentation', ed. Anne Kolb and Marco Vitale (forthcoming). SB XVIII 13167 (2. cent. CE): Hermann Harrauer and Pieter Johannes Sijpesteijn, "Ein neues Dokument zu Roms Indienhandel, P.Vindob. G 40822," AAWW 122 (195), 124-155. For connectivity in the ancient world see Peregrine Horden and Nicholas Purcell, The Corrupting Sea: A Study of Mediterranean History (Oxford, 2000). 
routes that linked the Atlantic to the Indian and the Pacific oceans during the Roman imperial period and betrays the comprehensive global connectivity of the ancient world.

A few major trading routes into Asia, Arabia, India and China deserve to be singled out for the purposes of this paper. The so-called 'Silk Road' or 'Silk Routes' (not an ancient term) consisted of an entire network of trading routes that linked the Mediterranean and China by land and sea. ${ }^{4}$ Herodotus already mentioned the northern route connecting the Black Sea with Central Asia. ${ }^{5}$ It led via the Caucasus and the Caspian Sea to the Oxus river (Amu Darya) and from there via modern Afghanistan towards India and China. The 'Scythian gold', among other things, might have been brought to the West via this route. The southern route started at Syrian Antioch and led via Palmyra, the Parthian empire and Samarkand to Kashgar where it split into a northern and southern branch leading around the Tarim Basin and the Taklamakan desert. The two branches re-united at the so-called "Jade-Gate" from where they led to Dunhuang and Xi'an. Ancient Chinese sources reveal the strategic importance that was attributed to this long distance trade route, for according to these texts, the Romans had always wanted to be in direct contact with the Chinese, but the Parthians, wishing to control the intercontinental silk trade, prevented them from doing so. ${ }^{6}$

The so-called 'Incense Route', again a term not for a single route but for an entire network of routes, connected the Mediterranean port of Gaza via Petra, the capital of the Nabataean kingdom, with the southern parts of the Arabian Peninsula and the Persian Gulf. From a Mediterranean perspective, the 'Incense Route' afforded the import of frankincense, myrrh, spices and other precious goods from South Arabia, India and East Africa. Control of the

4 See most recently John E. Hill, Through the Jade Gate to Rome. A Study of the Silk Routes during the Later Han Dynasty ist to 2nd Centuries CE. An Annotated Translation of the Chronicle on the 'Western Regions' in the Hou Hanshu (Charlestone, 2009). Liu Xinru, The Silk Road in the World History (Oxford, 2010). For an overview see also Marek Jan Olbrycht, "Die Geschichte der Seidenstraße in antiker Zeit," in Die Krim. Goldene Insel im Schwarzen Meer. Begleitbuch zur Ausstellung in Bonn (Darmstadt, 2013), 67-87.

5 Hdt. 4,11. 17-23. 101.

6 Hou Hanshu 12: cf. Hill, Jade Gate (see above, n. 4), p. 27 and Donald Daniel Leslie and Kenneth Herbert James Gardiner, The Roman Empire in Chinese Sources (Rome, 1996), p. 51. Wei Lüe 11: cf. John E. Hill, The Peoples of the West from the Weilüe 魏略 by Yu Huan 魚䅈: A Third Century Chinese Account Composed between 239 and 265 CE. Draft annotated English translation. http://depts.washington.edu/silkroad/texts/weilue/weilue.html (8. Jan. 2014). section 11 and Leslie and Gardiner, p. 70. Cf. also Friedrich Hirth, China and the Roman Orient (Shanghai and Hongkong, 1885), p. 42. 
northern end of the caravan routes turned the Nabateans into middlemen in this trade, and made them rich. The Roman provincialisation of their kingdom in the year $106 \mathrm{CE}$ by the emperor Trajan, not only led to a new distribution of wealth and power in the region, but it also entailed the establishment of new institutions and infrastructure that facilitated the further development of long distance trade, including measures to increase security on land and sea and the construction of a direct road from Damascus via Bosra and Philadelphia to Aila on the Gulf of Aqaba. ${ }^{7}$

The 'discovery' of the monsoon winds in the second century BCE marked the beginning of a sea-borne long distance trade that established new and upgraded existing links between the Mediterranean and the countries on the Red Sea and Indian Ocean. Initially, this put the Ptolemies in the lucrative position of middlemen (thereby fuelling their rivalry with the Nabateans). Sea routes eventually linked the Ptolemaic and Roman harbors on the Red Sea with the South Arabian kingdoms, East Africa, India and Sri Lanka, Vietnam and China. The Ptolemies (and later the Romans) fostered this commerce by constructing ports, developing routes and, most important, by aiming to establish security along the coasts of the Red Sea. The Roman takeover of the Ptolemaic kingdom of Egypt in 30 BCE sparked a major increase in economic activities on the Red Sea and the sea routes to India. It also led to high revenues for the Roman treasuries from taxing the Indo-Mediterranean trade, as well as to diplomatic contacts with rulers of far away countries. ${ }^{8}$

To be sure, the connectivity of the Mediterranean basin with other parts of the ancient world neither depended on the existence of Roman roads nor on that of the Roman Empire. This is clearly borne out, for instance, by Ashoka's thirteenth 'Rock Edict' from Kandahar from around 250 BCE, which refers to embassies that the Indian Maurya king sent to the Hellenistic courts of Antiochos II Theos, Ptolemy II Philadelphos, Antigonos Gonatas, Magas of Cyrene and Alexander II of Epirus (?). ${ }^{9}$ Yet Strabo's claim that traffic between Egypt and India increased six-fold as a nearly immediate consequence of the Roman takeover of the former Ptolemaic kingdom of Egypt illustrates

7 Cf. Speidel, "Wars, trade, and treaties" (see above, n. 2).

8 Ibid.

9 Ulrich Schneider, Die großen Felsen-Edikte Asokas: kritische Ausgabe, Übersetzung und Analyse der Texte (Wiesbaden, 1978): Edict 13. See also Reinhold Merkelbach and Josef Stauber, Jenseits des Euphrat. Griechische Inschriften (München, 2005), p. 33 with further literature on p. 35. Cf. also Reinhold Merkelbach, "Wer war der Alexandros zu dem Ašoka eine Gesandtschaft geschickt hat?," EA $3^{2}$ (2000), pp. 126-128. For Hellenistic kings sending ambassadors to India see also Strabo 2,1,9.15,1,36. Plin., $N H$ 6,21,58. 
the enormous extent to which all aspects of international exchange appear to have increased in the wake of the establishment of the principate and the extension of Roman rule by Augustus and his successors. ${ }^{10}$ Lively descriptions of the effects of this increased global connectivity on people and communities have survived, for instance by Dio Chrysostomus for Alexandria or by Aelius Aristides for Rome." Dio Chrysostomos even held that the influx of Greeks, Italians, Syrians, Libyans, Cilicians, Ethiopians, Arabs, Bactrians, Scythians, Persians and Indians into Alexandria made them all a 'kindred people'

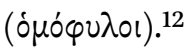

In spite of increased mobility and traffic since the late first century BCE, the effects of intercultural contacts evidently cannot be expected to have produced uniform transcultural knowledge and largely identical perceptions of the Roman Empire along the great eastern trade routes. Instead, we should expect local perceptions of the Roman Empire as a foreign power to have varied greatly according to time and place. It is no doubt mainly due to the great linguistic and methodological difficulties that such issues have not, so far, attracted much scholarly attention. Yet recent years have witnessed the publication of important and pertinent ancient texts with translations and commentaries by scholars from several different disciplines of ancient world studies. Few of these sources are generally known among students of ancient Mediterranean history, and some of these texts call for interpretations by historians of the Roman Empire. It seems apposite, therefore, to mention and comment on some of the most significant non-Roman assessments of the Roman Empire along the great Eastern trade routes.

\section{2 \\ Friends and Enemies}

Among the most famous ancient assessments of the Romans by a foreigner contained in a non-Roman source from the imperial period are no doubt the rock-face reliefs and the trilingual inscription at Naqsh-e-Rustam that glorify the deeds of the Sassanid king Shapur I. ${ }^{13}$ As this monument celebrates the king's grand victories over Roman troops, his invasions into Roman territories, and his capture of the Roman emperor Valerian, it is not surprising that the Romans are portrayed as rightly defeated aggressors and as violators

\footnotetext{
10 Strabo 2,5,12. 17,1,13.

11 Dio Chrys., Or. $3^{2,36}$ and 39. Arist., or. Rom. 11-13.

12 Dio Chrys., Or. 32,36.

13 André Maricq, "Res Gestae Divi Saporis," Syria 35 (1958), pp. 245-26o.
} 
of international agreements. From the late second or early third century CE Edessa in northern Mesopotamia, two of the earliest Syriac literary texts contain statements that convey a similar sentiment: 'The Letter of Mara Bar Sarapion to his son' and the 'Book of the laws of the countries.' ${ }^{14}$ However, their historical background differs considerably from that of Shapur's inscription, as the authors of these texts were victims of Rome's expansion rather than victorious kings. Both Syriac texts probably date to the period between the later second and the early third century CE when Rome, in successive steps, invaded, occupied, and finally provincialized Northern Mesopotamia and its capital city Edessa on the Silk Road. 'The book of the Laws of the countries' refers to the Romans as an aggressive power that will not refrain 'from always conquering new territories', ${ }^{15}$ whereas 'The Letter of Mara Bar Sarapion', even describes the Romans as arrogant, violent, self-righteous, uncivilized and dishonest aggressors with questionable moral standards. Yet rather than being mere accusations against Roman aggression, these texts seem to be literary products by members of the former ruling elite that essentially advocated philosophic strategies of how to cope with a cruel fate that led to the loss of power, wealth and status in a period of political transition. ${ }^{16}$ In essence, they propose to leave power and wealth behind and to indulge in education (paideia) and philosophy, and thus, by taking the moral high ground, to reverse the makings of fate and to outclass the Roman conquerors.

14 'Mara Bar Sarapion': Annette Merz, David Rensberger, and Teun Tieleman, Letter to his son (Tübingen, forthcoming). See also Michael A. Speidel, "Making use of History beyond the Euphrates. Political views, cultural traditions, and historical contexts in the Syriac 'Letter of Mara Bar Sarapion,", The Letter of Mara bar Sarapion in Context. Proceedings of the Symposium Held at Utrecht University, 10-12 December 2009, ed. Annette Merz and Teun Tieleman (Leiden, 2012), pp. 11-41. 'Book of the Laws of Countries': Han J.W. Drijvers, The Book of the Laws of Countries. Dialogue on Fate of Bardaisan of Edessa, 2nd ed. with a new introduction by Jan Willem Drijvers (Piscataway, 2006).

15 Drijvers, Book, pp. 52-53: '... it (sc. 'Fate') does not prevent... the Romans from always conquering new territories.... Torsten Krannich and Peter Stein, "Das 'Buch der Gesetze der Länder' des Bardesanes von Edessa”, zAC 8 (2004), 203-229, esp., 225f. § 40: '... noch die Römer ständig andere Länder in Besitz zu nehmen..... Interestingly, Euseb., Praep.

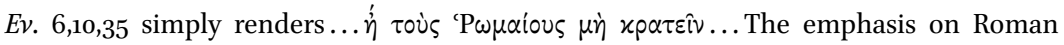
rule, rather than on continuous conquest is even more pronounced in the reworked ver-

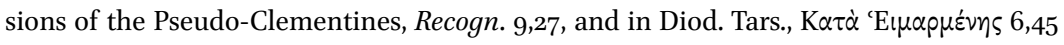
(for which see Illaria Ramelli, Bardaisan of Edessa: A Reassessment of the Evidence and a New Interpretation (Piscataway, 2009), 134-135). See also Drijvers, The Book, pp. 56-57: 'Recently the Romans have conquered Arabia...' (i.e. northern Mesopotamia). Krannich and Stein, "Das Buch", p. $227 \S 43$ : 'gestern (erst)'. Euseb., Praep. Ev. 6,10,41: $\chi \theta \dot{\varepsilon} \varsigma$.

16 Speidel, "Making use" (see above, n. 14), pp. 26-27 and 39-41. 
In this, the proposition of the Syriac texts, to some extent, appears to resemble that of the Pesher Habakkuk, a Hebrew text from the second half of the first century BCE preserved among the Dead Sea Scrolls. ${ }^{17}$ This interpretative commentary on the Book of Habakkuk repeatedly refers to the kittim, a term that is now practically universally taken to designate the Romans. Thus, written after Pompey's conquest of Jerusalem and the establishment of Roman supremacy over Judaea, the Pesher Habakkuk describes the kittim (modeled, of course, on the Chaldaeans of the Book of Habakkuk) as an evil and bellicose foreign power. They are said to be swift and formidable soldiers, inspiring all nations with fear, they wage wars to enrich themselves, they have conquered and pillaged many countries and, with their swords, mercilessly kill men, women, the old and children (even the unborn) alike. Collaborators and opportunists may become wealthy under this regime, but the Pesher predicts that from the hands of the kittim they will eventually suffer the same fate they inflict upon others. The text finally affirms that God will rescue those who maintain their faith and continue to live by his law, and that all others will suffer his retaliation on the Day of Judgement, thus (not unlike the Syriac texts mentioned above) predicting the ultimate victory of the righteous.

Further evidence comes from graffiti carved on rocks in an Ancient North Arabian dialect, Safaitic, by nomads from the eastern fringes of the Roman Empire in southern Syria, north-eastern Jordan, and northern Saudi Arabia. These Safaitic graffiti from between the first century BCE and the fourth century CE often provide vivid glimpses of the daily life of these nomads. They include some 30 inscriptions which mention either the author's relations with (or attitude towards) the $\mathrm{rm}$ (which, perhaps, not in all cases refers to the Romans') or which are dated to events involving the Romans or their emperor. ${ }^{18}$ In general, these inscriptions convey the impression not primarily 'of 'insiders' and 'outsiders', but of constant symbiosis and communication-as well as

17 1QpHab. For what follows see e.g. William H. Brownlee, The Midrash Pesher of Habakkuk (Ann Arbor, 1979). Moshe J. Bernstein, "Pesher Habakkuk," in Encyclopedia of the Dead Sea Scrolls (Oxford and New York, 200o), pp. 647-650. Michael O. Wise, Martin G. Abegg Jr., and Edward M. Cook., The Dead Sea Scrolls: A New Translation. (San Francisco, 2005) pp. 83-86. Leonhard Burckhardt, "Rom und die Juden nach der Eroberung Palästinas durch Pompeius," DHA Suppl 9 (2013), pp. 59-76, esp. 70-74.

18 For what follows see M.C.A. Macdonald, 'Romans go home'? Rome and other 'outsiders' as viewed from the Syro-Arabian desert. In: J.H.F. Dijkstra and G. Fisher (eds.), Inside and Out. Interactions between Rome and the Peoples on the Arabian and Egyptian Frontiers in Late Antiquity. (Leuven, 2014), pp. 145-163. Cf. also Ulf Scharrer, "The problem of nomadic allies in the Roman Near East", in: M. Facella / T. Kaizer (eds.), Kingdoms and Principalities in the Roman Near East (Stuttgart, 2010), pp. 241-335, esp. 272-276. 
occasional conflict-between the nomads and the settled populations of the local kingdoms and Roman provinces of this region.19 ${ }^{19}$ Thus, there are texts that refer to 'the year [in which] Malichus king of Nabataea smote thirty centuries (?) of Roman soldiers', or to 'the year of the struggle between Rome and the Nabataeans', and to 'the year of the Nabataeans' rebellion against the Romans. ${ }^{20}$ None of these texts can be dated with any degree of certainty, yet some scholars have suggested they all belong to the period immediately following the Roman take-over of the Nabataean kingdom in $106 \mathrm{CE}$. While that cannot entirely be excluded, it is perhaps more (or at least just as) likely that (most of?) these inscriptions refer to hostilities between the Romans and the Nabataeans after Pompey's creation of provincia Syria in 63 в Се. One text refers to 'the year Caesar sent reinforcements to the province and put the province in good order.21 This graffito has been dated to the reign of Septimius Severus and, in any event, seems to convey an approving attitude of its nomadic author towards Roman rule in the region. The same seems to be true for the authors of another group of Safaïtic graffiti which refer to military service for Rome in units composed entirely from members of their tribes. Yet, there is also at least one episode of military brutality against a civilian on record, as well as some texts in which the authors say they were running away from the Romans or from Roman territory.

The authors of these Safaitic texts were likely thinking of Roman soldiers (irrespective of their origins) when they referred to 'the Romans'. The graffiti therefore probably refer to the relations of these nomads with the Roman army and authorities. It is hardly surprising that texts presenting Rome primarily as a military power originate from the fringes of the Empire where military action against the enemies of Roman order (as well as Roman soldiers' abuse of power) would evidently have occurred more often than elsewhere. Yet, as is well known, Rome also had staunch supporters in these regions on both sides of the Empire's provincial frontiers. Such friends of Rome did not hesitate to publically advertise their loyalty to Rome and to praise Roman victoriousness. An explicit example of this comes from the Hisma, a remote region in southeast Jordan through which the 'Incense Road' ran. It was here that a man named Laurikios carved a graffito in Greek language on a rock:22

\footnotetext{
19 Macdonald, Romans, p. 145.

$20 \quad$ Macdonald, Romans, p. 153 f.

21 Macdonald, Romans, p. 155.

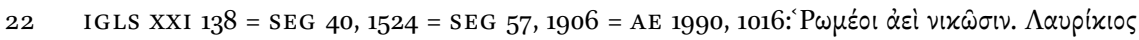

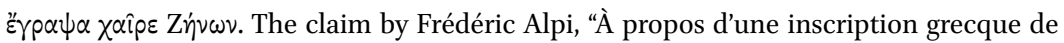
la Hisma," Mélanges de l'Université Saint-Joseph LX 2007 (= Mélanges J.-P. Rey-Coquais)
} 


\section{The Romans always win. I, Laurikios wrote (this). Hail Zenon!}

Clearly, Laurikios rejoiced in Roman victoriousness, which in the context of this graffito most likely refers to local, small-scale engagements of the Roman army with brigands and other enemies of the Roman order in the region. ${ }^{23}$ Zenon might indeed, as has been suggested, be the same man mentioned in a nearby Nabataean graffito (from perhaps around the mid-second century $\mathrm{CE}$ ), in which he is described as a tribune (KLYRK $=\chi(\lambda i \alpha p X \eta \varsigma)$, and as the son of a man with an Arabic name (QYMT). ${ }^{24}$ If the term was used in its technical sense, Zenon, was an Arab commander of a milliary auxiliary unit of the Roman army who could read and write Nabataean, read and understand Greek, as well as,

(Beirut, 2007), pp. 335-353, esp. 343-344 that the inscription consists of two distinctly different graffiti is neither borne out by the photograph in his Fig. 2 on p. 337 nor by his drawing in Fig. 5 on p. 342, and therefore remains unconvincing. There is also no need to date the graffito to the 4 th -7 th c. CE based on late Roman and Byzantine 'Nika-Akklamations', as suggested by Alpi.

23 Thus also Scharrer, "The problem" (see above note 18), p. 276 with further bibliography. The alterity conveyed by Laurikios' use of the expression 'the Romans' is, by itself, not a reliable guide to whether or not he counted himself among the subjects of the Roman Empire: For Greek and early Syriac literature of the first centuries CE using the expression 'the Romans' to denote historical and contemporary representatives of the Roman state see Speidel, "Making use" (see above, n. 14), p. 15 and cf. p. 27 with n. 55. With particular reference to Roman soldiers in Late Roman and Byzantine literature: Alpi "À propos", pp. 349-350. For the Roman army fighting brigands along the trade routes as a possible context for this graffito see esp. SB 1,4282 = I. Pan du désert 87 and O. Krok. 87 from Egypt's eastern desert. Cf. Hélène Cuvigny, Ostraca de Krokodilô. La correspondance militaire et sa circulation (Cairo, 2005), p. 135.

24 William J. Jobling, "Aqaba-Ma'an Survey, Jan.-Feb. 1981," Annual of the Department of Antiquities of Jordan 26 (1982), pp. 199-209: šlm Zynwn br Qymt klyrk bb l'lm ('Greetings! Zenon son of QYмт, Tribune, for good, forever'). Cf. R. Godfrey Tanner, “Greek Epigraphy in South Jordan," ZPE 83 (1990), pp. 183-193, esp. 184-188. Benjamin Isaac, The Near East under Roman Rule. Selected Papers (Leiden, 1998), p. 341. For a different view: D. Graf, "The Nabataean Army and the cohortes Ulpiae Petraeorum," in E. Dąbrowa (ed.), The Roman and Byzantine Army in the East (Krakow, 1994), 265-305, esp. 282. Alpi, "À propos", esp. pp. 337, 339, and 347. The well-known bilingual (Greek-Nabataean) inscription from Ruwwafa in the Hejaz (AE 1977, 834 = SEG 39, 1390, cf. SEG 51, 2290) recording the dedication of a temple to the Emperors Marcus Aurelius and Lucius Verus in 166/169 CE is not, as often held, from beyond the frontiers of the Roman Empire, but from within provincia Arabia: Glen W. Bowersock, Roman Arabia (Cambridge, MA, 1983), pp. 156-157, now confirmed: Michael A. Speidel, Heer und Herrschaft im Römischen Reich der Hohen Kaiserzeit (Stuttgart, 2009), pp. 633-635. See also Michael C.A. Macdonald, Literacy and Identity in Pre-Islamic Arabia (Farnham, 2009), pp. 1-26. 
no doubt, some Latin. Yet whether or not both men were identical is perhaps less important in the present context than the message these short inscriptions permanently conveyed to passers-by. For the latter hardly just included Roman soldiers and members of local communities, but also any brigands in the area (or other enemies of the Roman order) as well as traders and caravans on the 'Incense Route'. They were all reminded of the Roman army's success at keeping up or restoring security in the region. No doubt, Zenon and his fellow members of the Roman army were all delighted to read messages of the kind Laurikios left behind.

However, not all foreigners thought of the Roman Empire in terms of a great military power. Ancient Chinese historiographical texts, for instance, have nothing at all to say about the Roman armed forces or their battlefield successes. These texts refer to the Roman Empire by the term 'Da Qin', Greater China, 'apparently thinking of it as a kind of counter-China at the other end of the world'. ${ }^{25}$ Although 'Da Qin' is described as a particularly large (and, by implication, powerful) state with many dependencies, there are no Chinese descriptions of Rome's army, military capacity or martialness. ${ }^{26}$ Rather, these texts simply praise the Romans as 'tall and honest.'. ${ }^{27}$

It is of course impossible to determine whether allied and dependent kings such as Tigranes III and Artavasdes III of Armenia, or Rhoemetalkes I of Thracia also cherished such idealistic concepts of Rome and her ruler when they added an image of Augustus to their coinage. ${ }^{28}$ Artavasdes III even included a legend claiming that Augustus was a benefactor (euergetes). Yet these kings owed their position to Augustus, and therefore their official appraisal of splendid relations with the Roman ruler was an entirely political statement. ${ }^{29}$ Moreover, like most of Rome's foreign friends, they lived within

25 Edwin G. Pulleyblank, "The Roman Empire as Known to Han China," JAOs 119 (1999), pp. 71-79, esp. 71. Cf. also Krisztina Hoppál, "The Roman Empire According to the Ancient Chinese Sources," Acta Ant. Hung. 51 (2011), pp. 263-306, esp. 270. Yu Taishan, "China and the Ancient Mediterranean World. A Survey of Ancient Chinese Sources," Sino-Platonic Papers 242 (2013), pp. 1-268, esp. 28-29.

26 Cf. Leslie and Gardiner, The Roman Empire (see above, n. 6), p. 260.

27 Hou Hanshu 11: Hill, Jade Gate (see above, n. 4), p. 25.

28 Tigranes III and Artavasdes IV of Armenia: RPC I 3841. 3843. Anahit Mousheghian and Georges Depeyrot, Hellenistic and Roman Armenian Coinage (1 st c. BC-1st c. AD) (Wetteren, 1999), pp. 187-188 with table VIII, 169-170. IK 65, 472. Rhoemetalkes I of Thracia: RPC I 1708-1710.

29 For similar cases cf. e.g. Michael H. Crawford, Coinage and Money Under the Roman Republic: Italy and the Mediterranean Economy (Berkely, 1985), pp. 273-275. Fergus Millar, "Emperors, Kings, and Subjects: The Politics of Two-Level Sovereignty," in idem, 
the reach of Roman arms, and therefore may not always have felt entirely free to make their own political choices. For, as Eutropius $(8,8)$ ascertains, Rome's influence among her foreign allies rested as much upon veneration (veneratio) as on fear (terror). In any event, by including Augustus' portrait on their coinage they disseminated a symbol of loyalty to Rome, not a statement of their personnel assessment of Augustus or the Roman Empire.

It is therefore, perhaps, surprising to find the portrait of Augustus on a series of Sabaean coins from the Yemen. ${ }^{30}$ South Arabia is not usually counted among the regions that were under Roman control. Yet, the only plausible reason for Sabaeans to copy a portrait of Augustus (or any other Roman emperor) onto their coins seems to be that they too intended to send a signal of political loyalty to Rome in the same way that other allied kings and dynasts did in this period. ${ }^{31}$ Moreover, the Periplus maris Erythraei relates that the mid-first century 'legitimate ruler' ( $\varepsilon v \theta \varepsilon \sigma \mu \circ \varsigma \beta \alpha \sigma \lambda \lambda \varepsilon \dot{\varsigma} \varsigma)$ of the Sabaeans and the Himyarites,

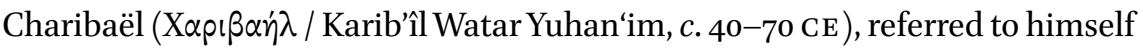

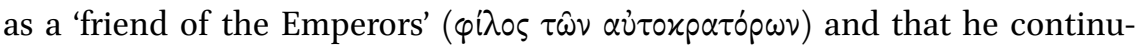
ously sent 'embassies and gifts' to the Romans. ${ }^{32}$ If this choice of words indeed reflects official Roman terminology, as seems likely, it implies that the kings of Saba and Dhu Raydan (= Himyar) had entered a state of political friendship (amicitia, cf. below) with Rome and were now among Rome's dependent allies. Further documentary evidence can be shown to corroborate this interpretation. Surely, Sabaean and Himyarite amicitia with Rome was, at least initially, the result of a military expedition, which the Roman general Aelius Gallus led to Southern Arabia in 26 / 25 BCE. Yet this alliance no doubt significantly contributed towards increased security along the maritime and terrestrial trade

Government, Society, and Culture in the Roman Empire, vol. II. (Chapel Hill, 2004), pp. 229-245.

30 Coins: BMC Arabia 32-48. Daniel T. Potts, "Augustus, Aelius Gallus and the Periplus: A Re-Interpretation of the Coinage of Șan'â' Class B," in Arabia Felix: Beiträge zur Sprache und Kultur des vorislamischen Arabien, Festschrift Walter W. Müller zum 6o. Geburtstag, ed. N. Nebes (Wiesbaden, 1994) 1-12, confidently identifying the portrait as that of Augustus on pp. 214-215. Stuart Munro-Hay, Coinage of Arabia Felix. The Pre-Islamic Coinage of the Yemen (Milano, 2003), 47-48. Martin Huth, Coinage of the Caravan Kingdoms-Ancient Arabian Coins from the Collection of Martin Huth. Ancient coins in North American collections, 10 (New York, 2010), xx-xxi and 100-101 ('Roman style bust', 'resembling bust of Augustus').

Cf. above n. 24 and 25 as well as e.g. the coins of Ajax, highpriest and toparch of eastern Cilicia Tracheia (RPC I 3724. 3726. 3727) or Philip, tetrarch of Gaulanitis (RPC I 4938-43). $P M E$ 23. For embassies from Southern Arabia to Rome see also Plin., $N H 12,31,56$. 
routes in the wider region, thus facilitating trade and increasing its volume, which soon benefitted both sides. ${ }^{33}$

If public displays of the attitudes of foreign rulers and dynasts towards Rome were closely monitored and interpreted within the framework of transnational political communication, ordinary citizens from communities beyond the empire's boundaries, it seems, enjoyed a little more freedom in proclaiming their personal political opinion of Rome in their everyday lives. That, at any rate, is what Dio Chrysostomos implies in an episode from the Greek colony of Olbia on the northern shore of the Black Sea, where he passed through during the later first century CE. ${ }^{34} \mathrm{He}$ described the inhabitants of this colony that was situated on an important salt road as a community of long-bearded, backward Greeks, whose dialect was incomprehensible but whose beards would have thrilled a philosopher. Only one citizen of this colony, Dio claims, was clean shaven-out of flattery to the Romans. In the eyes of his Olbian fellow citizens such behavior was disgraceful and unseemly for real men. The episode may be greatly exaggerated or distorted, but Dio apparently expected his audience to believe it. Yet outward appearance and dress was of course not always intended to convey political statements. Thus, such motives were hardly foremost on the minds of the many people from the southern Red Sea and around the 'Horn of Africa' who are reported to have bought (and surely also wore) imported 'Roman' style clothes. ${ }^{35}$

\section{Trade and Friendship}

Nor were all political statements by foreign rulers concerning Rome motivated by anxiety. Thus, fear of Rome's military power can hardly have motivated Kujula Kadphises (ca. 30-8o CE), the first Kushan ruler, to strike the bust of a Julio-Claudian emperor on the obvers of a series of coins he minted at Taxila (near modern Islamabad in Pakistan). ${ }^{36}$ Even more surprisingly, the revers side

33 The argument is set out in full in Speidel, "Wars, Trade, and Treaties" (see above, n. 2). For a discussion of the evidence see also Michael A. Speidel, 'Almaqah in Rom?, ZPE 194 (2015) 241-258. Cf. also below.

34 Dio Chrys., Or. 36,17. Cf. e.g. David Braund, "Greeks and Barbarians: The Black Sea Region and Hellenism under the Early Empire," The Early Roman Empire in the East, ed. Susan Alcock (Oxford, 1997), pp. 121-136, esp. 126-129.

35 PME 6. 8-10.12-13.

36 John Marshall, Taxila. 3 vols. (Cambridge, 1951), vol. 2, p. 544. Rafique A. Jairazbhoy, Foreign Influence in Ancient India (Bombay, 1963), p. 120. David MacDowall, "Numismatic Evidence for the date of Kanişka," in Papers on the date of Kanişka, London, 20-22 April 
of these coins shows the Kushan ruler in Indo-Scythian dress sitting on what remarkably looks like a sella curulis. As seats of this type are not known to have belonged to the contemporary domestic culture of northern India, it is generally held that this image refers to a real Roman sella curulis. If correct, it might have been given to one of the numerous Indian missions on record that came to Rome seeking amicitia, for giving presents to successful such embassies is a well-documented Roman practice, and there are a number of known cases where the Roman grant of amicitia was underpinned by presenting a sella curulis (and other gifts) to the new amicus. ${ }^{37}$ Incidentally, what appear to be the actual remains of such a sella curulis have been unearthed during excavations at Taxila where the above-mentioned coins are believed to have been struck. ${ }^{38}$

If correct, the historical context of these coins is probably connected to diplomatic contacts with Rome. ${ }^{39}$ Augustus proudly records in his 'Achievements' that 'embassies of kings from India were often sent to me, such as previously have never been seen in the presence of any Roman leader. ${ }^{40}$ The immediate

1960, ed. A.L. Basham (Leiden, 1968), pp. 34-149, esp. 144 n. 4. Karl-Uwe Mahler, “Augustus und Kujula Kadphises, Herrscher der Kuschan," in Augustus—Der Blick von Aussen. Die Wahrnehmung des Kaisers in den Provinzen und in den Nachbarstaaten, D. Kreikbom et al. ed., (Wiesbaden, 2008), pp. 297-319, esp. 301-303.

37 David Braund, Rome and the Friendly King. The Character of the Client Kingship (London, 1984), pp. 34-35.

38 Marshall, Taxila, vol. 2, p. 544 no. 54 and vol. 3, p. 170 no. 54 .

39 For diplomatic contacts between Rome and India in the first century CE (with the references) see e.g. Gabriele Ziethen, "Legationes Externae in der frührömischen Kaiserzeit:

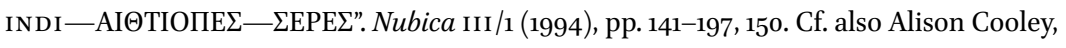
Res Gestae Divi Augusti. Text, Translation, and Commentary (Cambridge, 2009), 249-251 and Raoul McLaughlin, Rome and the Distant East. Trade Routes to the Ancient Lands of Arabia, India, and China (London, 2010), pp. 111-120. Later references in the sources include Dio 68,15,1 (106 CE), an ancient South Arabian inscription: Joëlle Beaucamp, Françoise Briquel-Chatonnet, and Christian J. Robin, "La persécution des chrétiens de Nagrān et la chronologie himyarite," Aram 11-12 (1999-2000), pp. 15-83, esp. 70 (ca. 218/19 CE?). HA Aurel. 33,4 (270 CE). Euseb., v.Const. 4,50 (336/7 CE). Amm. 22,7,10 (361 CE). Malalas 477 (530 CE).

$40 \quad \operatorname{RgdA}$ 31. See also Suet., Aug. 21,3. In particular: Oros., 6,21,19-20. Dio 54,9,8. Strabo 15,1,4. Plin., $N H 8,25,65$. As only two Indian embassies are independently known to have met Augustus, Cooley, Res Gestae, pp. 249-250 concludes that the Roman ruler unduly exaggerated diplomatic contacts with India in order to propagate the idea that his influence won friends from Rome even in the remotest parts of the Ancient World. Yet even though there can be no doubt that Augustus made the most of the arrival of Indian embassies, that by itself is not a compelling reason to question his statement all together, or to 
textual context of this statement within the res gestae implies that the Indian ambassadors came to ask for 'friendship' (amicitia) with Augustus and Rome, and that is indeed what Suetonius explicitly states. ${ }^{41} \mathrm{In}$ fact, whenever ancient reports of embassies from India provide any context or purpose at all, the envoys are always presented as seeking 'friendship' (amicitia, $\varphi$ i $\lambda i \alpha)$ with Rome. Surely, foreign envoys hardly travelled all the way to meet the Roman ruler simply to exchange empty politenesses. Unfortunately, the term amicitia by itself is no guide to the specific type or terms of a treaty (formal or informal), ${ }^{42}$ and the Roman narrative sources need not be comprehensive in this respect, as they are almost exclusively concerned with the political and military aspects of treaties. Suetonius held that foreign embassies from far-away countries sought Augustus's (and the Roman people's) friendship because of the renown of the Roman ruler's bravery and moderation. At least in some parts of the ancient Middle East reports of the vast and unparalleled powers of the Roman

believe that the other surviving sources reveal the entirety or even the majority of diplomatic contacts between India and Rome in the Augustan period.

$\operatorname{RgdA} 31$ continues by evoking envoys of the Bastarnae, Scythians, Sarmatians, Albanians, and Hiberians, and immediately begins with nostram amicitiam appetiverunt ..., implying that this statement, which linked the two sentences, was also true for the Indian envoys. Suet., Aug. 21: qua virtutis moderationisque fama Indos etiam ac Scythos auditu modo cognitos pellexit ad amicitiam suam populique Romani ultro per legatos petendam. For a recent assessment of the notion of amicitia with respect to Roman empire-building see Paul J. Burton, Friendship and Empire: Roman Diplomacy and Imperialism in the Middle Republic (353-146 BC) (Cambridge, 2001). For the importance of political amicitia for the Indo-Mediterranean trade in the imperial period see Michael A. Speidel, "Fernhandel und Freundschaft. Zu Formen römischer Wirtschaftsförderung am Roten Meer und am Indischen Ozean," (Orbis Terrarum 14, forthcoming).

42 For discussions of the correlation between amicitia and formal treaties see e.g. Alfred Heuss, Amicitia. Untersuchungen zu den rechtlichen Grundlagen der römischen Außenpolitik(Gräfenhainichen, 1933), esp. 55. Dieter Timpe, "Rechtsformen der römischen Aussenpolitik," Chiron 2 (1972), pp. 277-295, esp. 288. Christof Schuler, "Ein Vertrag zwischen Rom und den Lykiern aus Tyberissos," in: Griechische Epigraphik in Lykien. Eine Zwischenbilanz, ed. C. Schuler(Wien, 2007), pp. 51-79, esp. 64-65. Altay Coşkun, "Rückkehr zum Vertragscharakter der amicitia? Zu einer alt-neuen Forschungskontroverse," in Freundschaft und Gefolgschaft in den auswärtigen Beziehungen der Römer (2. Jahrhundert v. Chr.-1. Jahrhundert n. Chr., ed. A. Coşkun (Frankfurt a.M., 2008), pp. 209-230. Peter Kehne, "Feinde und Partner Roms," in Kontaktzone Lahn. Studien zum Kulturkontakt zwischen Römern und germanischen Stämmen, ed. Kai Ruffing, Armin Becker, and Gabriele Rasbach (Wiesbaden, 2010), pp. 31-65, esp. 42-43. Andreas Zack, "Forschungen über die rechtlichen Grundlagen der römischen Außenbeziehungen während der Republik bis zum Beginn des Prinzipats," Teil I-III, GFA 14-16 (2011-2013), pp. 47-119, 61-128, 63-113. 
emperors indeed seem to have left a deep impression with local dynasts. ${ }^{43}$ That, at any rate, is what the use of the title Kaisar by the Kushan ruler Kanishka II (ca. $225^{-245} \mathrm{CE}$ ) appears to imply. ${ }^{44}$ Whether, as has often been assumed, the name Gesar of the hero of Tibet's classic epic derived from the Latin imperial title Caesar is perhaps less than certain. ${ }^{45}$

Surely, for amicitia to exist or to be recognized as a state of international 'friendship' beyond the reach of Roman arms, it needed to satisfy certain expectations on both sides, even if imperial Rome thought of itself as (and behaved like) the dominant power. John Thorley argued that Kushan wealth was based, to a significant extent, on trade with the Roman Empire. ${ }^{46}$ Unfortunately, our sources fail to explicitly clarify whether and to what extent the Indian embassies to Rome were commercially motivated. It is suggestive, therefore, that the arrival of the earliest embassies from India under Augustus coincided with an enormous increase in the volume of Indo-Mediterranean trade..$^{47}$ Moreover, some of the better known treaties establishing or confirming amicitia with Rome may indicate, by analogy, that facilitating trade and increasing its volume was indeed among the intentions that led both Romans and Indians to conclude such agreements of friendship. Thus, the earliest treaties with Carthage (508/7 and 348?), which are generally held to be wholly economic in contents, and which according to Moses Finley were among the very few international trade agreements that Rome ever concluded began, according to Polybios, with the words: 'There shall be friendship $(\varphi i \lambda i \alpha)$ between the Romans $(. .$.$) and the Carthaginians (...) on the following conditions:.....48$

43 Suet., Aug. 21: qua virtutis moderationisque fama. The emperor Antoninus Pius is said to have had such unmatched prestige (auctoritas) among foreign nations (HA Ant. Pius 9,10) that they referred their controversies to him (Eutrop. 8,8) and that even the Indi, Bactri, and Hyrcani (Epit. de Caes. 15,4) sent embassies to Rome seeking his just decision (iustitia). Cf. also the text to n. 53 , below.

44 John Thorley, "The Roman Empire and the Kushans", G \& R 26 (1979), pp. 181-19o, esp. 185186. Hermann Kulke and Dietmar Rothermund, A History of India, 4th edition (Abingdon, 2004), p. 83. McLaughlin, Rome (see above, n. 35), pp. 128-131.

45 Cf. e.g. Stephan V. Beyer, The Classical Tibetan Language (New York, 1992), p. 140. Li Lianrong, "History and the Tibetan Epic Gesar," Oral Tradition 16 (2001), pp. 317-342. Kurtis R. Schaeffer, Matthew Kapstein, and Gray Tuttle, eds., Sources of Tibetan Tradition (New York, 2013), p. 309.

46 Thorley, "Roman Empire” (see above, n. 39), p. 189.

47 Strabo 2,5,12. 17,1,13.

48 Polyb., 3,22,4 and 3,24, 3-13. John Serrati, "Neptune's Altars: The Treaties between Rome and Carthage (509-226 B.C.)," CQ 56 (2006), pp. 113-34, esp. 113 and 120. Cf. Moses Finley, The Ancient Economy (Berkeley, 1973), p. 161. 
The evocation of amicitia in the opening passage of these Roman trade agreements strongly suggests that amicitia could indeed be seen to have entailed important economic implications from Rome's earliest history onwards. One such implication concerned piracy, which the early treaties with Carthage apparently aimed to reduce. ${ }^{49}$ The link between amicitia and the fight against piracy is also borne out by the lex de provinciis praetoriis of $100 \mathrm{BCE} .{ }^{50}$ For this text, which deals with the provincial organization of Cilicia and Macedonia, the suppression of piracy and the administration of newly conquered territories, relates how Roman magistrates could address letters to eastern kings who had friendship and alliance with Rome, instructing them not to support or tolerate piracy but to help the Romans provide safety according to justice and the laws.

A recently published bronze tablet inscribed with the text of a treaty between Rome and the commune of the Lycians from 46 вСЕ provides further insight. ${ }^{51}$ It begins by confirming the state of $\varphi\left(\lambda i \alpha\right.$ (= amicitia), ${ }^{52}$ which, as we know from another recently published epigraphic copy of an earlier treaty, already existed between the two partners. ${ }^{53}$ Among other things, the remaining parts of the treaty of 46 вСЕ contain regulations of substantial economic significance. Thus, the new treaty refers to the previous mutual promise of military support (which evidently included fighting pirates), and then adds a new clause that specifies the relationship between Rome and her free allies with regard to criminal and civil cases. By confirming and spelling out the Lycians' right to be tried for capital offences according to their own laws in their native country, this clause not only endorsed a privilege to their communality but it also contributed to the legal security of travellers and merchants (or at least it can be understood to have done so) for if a dispute arose, those involved could

49 See Walter Ameling, Karthago: Studien zu Militär, Staat und Gesellschaft (München, 1993), 130-140.

$5^{0}$ IK 41, no. 31. Michael H. Crawford et al. (eds.), Roman Statutes, vol. I (London, 1996), no. 12. Cf. Jean-Louis Ferrary, "Recherches sur la législation de Glaucia," MEFRA 89 (1977), pp. 619-66o.

AE 2005, 1487 = SEG 55, 1452 = Bull. Ép. 2006, 146. For what follows see the excellent commentary by Stephen Mitchell, "The Treaty between Rome and Lycia of 46 вС (MS 2070)," in Papyri Graecae Schøyen (P. Schøyen I), ed. R. Pintaudi (Florence, 2005), pp. 161-258. Cf. also Schuler, "Ein Vertrag” (see above, n. 40). Pierre Sanchez, "La convention judiciaire dans le traité conclu entre Rome et les Lyciens (P.Schøyen I 25)," Chiron 37 (2009), pp. 363-381. Georgy Kantor, "SEG LV 1452, ll. 32-43, and the Crime of plagium in the Late Republic," ZPE 184 (2013), pp. 219-224, all with further bibliography.

$5^{2}$ It also included symmachia and koinonia.

53 Earlier treaty: AE 2007, 1504 = SEG 56, 1664. Schuler, "Ein Vertrag” (see above, n. 40). 
now consult a highly official text which was on public display. The clauses of this treaty therefore reassured both partners with respect to the efforts they would undertake to establish a safe environment within their respective realms, and they helped to prevent conflicts that could develop out of diverging notions of justice or interpretations of legal concepts. Thus, even though the treaty of 46 вСE also contained a new clause, by which the Lycians acknowledged the superiority of the Roman Empire, ${ }^{54}$ it also intended to establish a general context that was favorable to the trade relations between both partners, and thereby also promoted Lycian interests.

Flourishing around the mid-second century CE, the Roman jurist Sextus Pomponius also reflected on the correlation between political amicitia and international legal security. Thus, a fragment of his writings, which survives in the Digests reads: 55

... if there is neither friendship (amicitia) nor hospitium, nor a formal treaty made for the purpose of friendship (foedus amicitiae causa) between a particular people and us, they are not exactly our enemies, but anything, which belongs to us and passes under their control becomes their property, and a free man of ours who is captured by them becomes their slave.

It is not necessary for our present purpose to explore the entire range of legal and historical implications of this passage. ${ }^{56}$ It is enough to retain that in the mid-second century an eminent Roman jurist correlated the physical and legal security of Roman merchants in a foreign country with the existence of political amicitia (or hospitium or foedus amicitiae causa) between Rome and that country. Surely, it is also significant that Pomponius presents this correlation

54 For the 'Majestätsklausel' see Eugen Täubler, Imperium Romanum. Studien zur Entwicklungsgeschichte des Römischen Reiches (Leipzig, 1913), p. 64. Polyb. 21,32. Livy 38,11. I. Knidos 33 .

55 Dig. 49,15,5,2 (Pomponius, libro 37 ad Quintum Mucium):... nam si cum gente aliqua neque amicitiam neque hospitium neque foedus amicitiae causa factum habemus, hi hostes quidem non sunt, quod autem ex nostro ad eos pervenit, illorum fit, et liber homo noster ab eis captus servus fit et eorum: idemque est, si ab illis ad nos aliquid perveniat....

$5^{6}$ See Andreas Zack, "Forschungen über die rechtlichen Grundlagen der römischen Außenbeziehungen während der Republik bis zum Beginn des Prinzipats, I. Teil: Fragen an Sextus Pomponius: Quellen- und sachkritische Untersuchungen zu Pomponius 37. lib. ad Muc. D. 49,15,5," GFA 14 (2011), pp. 47-119 with the full relevant bibliography. In Zack's view (ibid., p. 108), amicitia-treaties, in Roman legal terms, were irrelevant to the safety of Roman and other ancient merchants. 
not as a phenomenon of a distant past but rather as a reality of his own days. Roman governments concluding and amending a variety of treaties and agreements within a framework that carried the label amicitia can therefore be understood to have been an important and common Roman response to the needs of international long distance trade (though Rome no doubt always kept its own benefit foremost in mind).

Of course this is not to suggest that there could not be or was no trade without treaties or a state of amicitia. But the sources referred to above suggest that the existence of amicitia reassured merchants and long distance traders. ${ }^{57}$ By concluding agreements of political friendship, Indian and other foreign rulers might therefore have hoped to increase the flow of commercial traffic from the Roman Empire into their realms. One might imagine, for instance, that the icon of a templum Augusti on the Peutinger map or the assurance of an Indian embassy to the emperor Constantine that their countrymen paid homage to the Roman emperor (of whom they allegedly kept paintings and statues) were somehow connected to such amicitia agreements. ${ }^{58}$ Be that as it may, Roman merchants involved in the trade with partners at Muziris would surely have rejoiced at the sight of the symbol of a templum Augusti on any comparable display or description of southern India. For such symbols no doubt implied a friendly attitude of local rulers towards Roman merchants and may even have hinted at the existence of a resident community or the repeated and regular presence of people from the Roman Empire (both of which are referred to repeatedly in the classical Tamil literature from the first centuries CE). ${ }^{59}$ Amicitia with Rome should have obliged the local Indian rulers to protect Roman merchants from pirates (which both the Peutinger map and the elder Pliny recorded in the region of Muziris).${ }^{60}$ The Periplus Maris Erythraei, perhaps, refers to such a case, for it mentions a situation of post-war turmoil at the

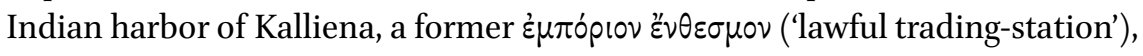

57 Compare Casson's remarks on hormoi apodedeigmenoi and emporion enthesmon in the Periplus Maris Erythraei: Lionel Casson, The Periplus Maris Erythraei. Text with introduction, translation, and commentary (Princeton NJ, 1989), pp. 271-277.

$5^{8}$ Euseb., v. Const. 4,50. For evidence of the imperial cult beyond the frontiers of the Imperium Romanum see Dieter Metzler, "Kaiserkult außerhalb der Reichsgrenzen und römischer Fernhandel," in Migratio et Commutatio. Studien zur alten Geschichte und deren Nachleben, ed. H.-J. Drexhage and J. Sünskes (St. Katharinen, 1989) 196-200, and Speidel, "Der Augustustempel" (see above, n. 3).

59 For western residents in Southern India see Pierre Meile, "Les Yavanas dans l'Inde tamoule," Journal Asiatique 323 (1940), pp. 85-123. Casson, The Periplus, pp. 24-25. MacLaughlin, Rome (see above, n. 35), pp. 18-19 and 55-56. 
and it informs its readers that Greek ships which by chance approached that harbor were escorted 'under guard' to the port of Barygaza. ${ }^{61}$

Evidently, the Indian Ocean was an area where the Romans had to achieve their political and economic goals by diplomacy and negotiation rather than by military superiority. Unfortunately, it is not known how many agreements of friendship between Rome and far away kings along the eastern trade routes existed at any given point in time. Nor is it possible to determine whether such monuments as the templum Augusti at Muziris or the Greek inscription on the statue base of a second or third century Roman emperor from the Himyarite capital of Zafar in modern Yemen, recently published by Christian Marek, are indeed products of political amicitia with Rome. ${ }^{62}$ However, the few cases that are on record imply that long distance trade could (and apparently often did) lead to the establishment of diplomatic contacts and political agreements, which the Romans called amicitia.

It thus appears that many rulers perceived agreements with Rome (or statements of mutual friendship) as an attractive means to facilitate trade. Of course, Roman emperors never hesitated to interpret, accept and promulgate requests by foreign rulers for amicitia as signs of submission, for in Roman eyes, accepting Roman domination was, of course, the ideal basis for political friendship. Also, at Rome, just as with the great empires of the Near and Far East, the influx of a great variety of exotic goods was understood to reflect the Empire's majesty. ${ }^{63}$ Conversely, it is not unlikely that Indian kings with good trade relations to Rome (and elsewhere) benefitted not only from the flow of trade as such but also from the symbolic value of popular foreign imports such as wine, coral or gold coins, simply by making them available to their subjects. ${ }^{64}$ Unfortunately, it is hardly ever possible to determine the precise symbolic value of any given product, which, in any event, would have varied depending on the recipient's location in society, space, and time. Nevertheless, the local value of imported goods directly reflected on the reputation of their country of origin as well as on the significance of their rulers. ${ }^{65}$ For when in $166 \mathrm{CE}$

$61 P M E$ 52. Cf. Casson, The Periplus, p. 215. MacLaughlin, Rome (see above, n. 35), p. 47. For a different view see Sunil Gupta, "Piracy and trade on the western coast of India," Azania 42 (2007), pp. 37-51, esp. 48-49.

62 Statue base: Christian Marek, "Zu neuen römischen Inschriften in Südarabien," Gymnasium 120 (2013), pp. 307-314.

63 Cf. e.g. Ov., Ars 3,113f. Tac., Ann. 2,6o. Arist., or. Rom. 12-13.

64 Sidebotham, Berenike (see above, n. 2), p. 251.

65 For a Roman assessment see Tac., Ann. 2,6o. For Sri Lanka: Plin., $N H$ 6,24,85 and Cosmas 11,338. For China: Hill, Jade Gate (see above, n. 4), p. 27. 
'envoys' of the Roman emperor Marcus Aurelius (or Antoninus Pius) arrived at the Chinese court with offers of rhinoceros horn, ivory, and turtle shell, the Chinese naturally took these gifts for tribute, but having expected jewels and exotica, they were not impressed and began to suspect that the wondrous accounts they had heard of the Roman Empire were all together exaggerated. ${ }^{66}$

With the exception of very rare instances like the one just referred to, there are no sources that indicate or imply regular direct interaction between the two great empires at the opposite ends of the Eurasian continent during the first three centuries CE. ${ }^{67}$ Still, a good number of historical accounts from the Later Han period (23-220 CE) onwards clearly attest to the collection of detailed information, by the Chinese, on the Imperium Romanum. ${ }^{68}$ However, Chinese conceptions of 'Da Qin' (the term, by which early Chinese historiography referred to the Roman Empire) 'were confused from the outset with ancient mythological notions' of a utopian empire in the far west. ${ }^{69}$ Such notions were evidently at the very origins of the term 'Da Qin', for it meant 'Greater China' and was not a transcription of a foreign name. ${ }^{70}$ Moreover, the existence of a 'Greater China' at the opposite end of the world conflicted with the ancient Chinese conception of the real world, which held that China (the 'Middle Kingdom') was its cultural center. According to this conception, the farther away a foreign people lived from the center, the more 'barbarian' they were

66 Leslie and Gardiner, The Roman Empire (see above, n. 6), p. 223. Hill, Jade Gate (see above, n. 4), p. 27 and cf. $292-293$.

67 Cf. Leslie and Gardiner, The Roman Empire (see above, n. 6), pp. 100-101, and 158-60.

68 Collected in Hirt, China (see above, n. 6). Leslie and Gardiner, The Roman Empire (see above, n. 6). See also Hill, The Peoples (see above, n. 6) and Hill, Jade Gate (see above, n. 4).

69 David F. Graf, "The Roman East from the Chinese Perspective," AAS 42 (1992), p. 199-216, esp. 199-200. Pulleyblank, "The Roman Empire" (see above, n. 21), p. 78. Hoppál, "The Roman Empire” (see above, n. 21), p. 264. Yu, “China” (see above, n. 21), pp. 69-70.

$70 \quad$ Pulleyblank, "The Roman Empire" (see above, n. 21), p. 71 and 77. Hill, Jade Gate (see above, n. 4), pp. 254-256. Hoppál, "The Roman Empire” (see above, n. 21), pp. 269-271. Yu, "China” (see above, n. 21), pp. 1-43. Remarkably, the earliest Chinese texts with references to Rome contain no transcriptions based on the name Roma or Imperium Romanum: Pulleyblank, "The Roman Empire" (see above, n. 21), p. 77. 
believed to be. ${ }^{71}$ But of course it was unthinkable that the people of 'Greater China' should have been the most uncivilized people on earth. Therefore they were portrayed as resembling 'the people of the Middle Kingdom, and that is why this kingdom is called Da Qin'.72 The Romans were described as 'tall and virtuous like the Chinese, but they wear Western clothes.' An explanation was also provided: 'They [i.e. the Romans] say they originally came from China, but left it. ${ }^{73}$

Such fanciful notions were complemented with information derived from true facts. Ever since Friedrich Hirth, in 1885, published his monograph China and the Roman Orient with a selection of ancient Chinese texts containing information on the Roman and Byzantine Empires (including translations and an extended commentary), these records have attracted scholarly attention, though primarily among Sinologists. ${ }^{74}$ For these texts provide information on the routes to and the communication with the Roman Empire and other 'Western Regions', on its geography, its capital, its administration and infrastructure, on dependent kingdoms, on its agriculture and stockbreeding, on textiles, perfumes and herbs, on other natural resources as well as on the population and their daily life. Two texts in particular deserve to be mentioned, the Hou Hanshu and the Wei Lüe. The Hou Hanshu is the official history of the Later (or 'Eastern') Han Dynasty $\left(25^{-221} \mathrm{CE}\right) \cdot{ }^{75}$ It was compiled mainly by a man named Fan Ye in the first half of the fifth century CE from earlier works, to which important sections from a now lost work (Xu Hanshu) by Sima Biao (240-306 CE) were added. These sections include a 'Chronicle on the Western Regions', which is primarily based on a report by Ban Yong to the emperor An

71 Cf. e.g. Herrlee G. Creel, Sinism. A Study of the Evolution of the Chinese World-View (Chicago, 1929). Q. Edward Wang, "History, Space, and Ethnicity: The Chinese Worldview," JWH 10 (1999), pp. 285-305.

72 Hou Hanshu 11: Hill, Jade Gate (see above, n. 4), p. 23.

73 Wei Lüe: Leslie and Gardiner, The Roman Empire (see above, n. 6), p. 7o. Hill, Jade Gate (see above, n. 4), p. 255.

74 Hirt, China (see above, n. 6). For bibliography see Leslie and Gardiner, The Roman Empire (see above, n. 6), pp. 3-6. Hill, Jade Gate (see above, n. 4), passim. Hoppál, "The Roman Empire" (see above, n. 21), pp. 266-269. Yu, "China" (see above, n. 21), pp. 43-127. For important remarks by an historian of the Roman Empire see Graf, "The Roman East" (see above, n. 64).

75 For what follows see Hill, Jade Gate (see above, n. 4), pp. xv-xxii with Burchard J. Mansvelt Beck, The Treatises of Later Han. Their Author, Sources, Contents and Place in Chinese Historiography (Leiden, 1990), p. 1, and Hans Bielenstein, The Restoration of the Han Dynasty, with Prolegomena on the Historiography of the Hou Han Shu (Stockholm, 1953), pp. 16-17. 
in c. $125 \mathrm{CE}$ and which replaced earlier accounts of the 'Western Regions.' ${ }^{76}$ This report included descriptions of the Roman Empire that stemmed from information the Chinese envoy Gan Ying had gathered during his mission to Da Qin. Although Gan Ying never actually reached the Imperium Romanum, he is said to have made it to the shores of the Persian Gulf in $97 \mathrm{CE}$, where he collected as much information on the Da Qin as he could. ${ }^{77}$ Other important sources of information may have resulted from the rare occasions of direct contact such as the Roman 'embassy' of $166 \mathrm{CE}$ which the Hou Hanshu records as having been sent from Āndūn, the king of Da Qin (i.e. Marcus Aurelius, or, perhaps, Antoninus Pius). ${ }^{78}$ The other early historiographical text containing important information on Da Qin, the Wei Lüe, is a chapter on 'Peoples of the West' from a now lost 'Brief Account of the Wei Dynasty', compiled at an unknown date in the third century CE by Yu Huan. ${ }^{79}$ The chapter has survived as an extensive quotation in a work of the fifth century. It both repeats earlier information on Da Qin (including much from the Hou Hanshu) and supplies valuable new material, which seems to date mainly to the second and early third century CE. ${ }^{80}$

Various problems are connected with the Chinese historical accounts and their interpretation. The compilation of these texts in ancient China was a bureaucratic procedure that involved much copying of earlier accounts and relied on records and archives. ${ }^{81}$ Thus, the precise origins and date of the underlying pieces of information and how they found their way to China often remains unknown, although diplomats, merchants and the great eastern trade

$7^{6}$ Hou Hanshu 1: Hill, Jade Gate (see above, n. 4), p. 13 and cf. p. 159.

77 On Gan Ying's mission and his much debated itinerary see Hou Hanshu 10: Hill, Jade Gate (see above, n. 4), pp. 23 and 481-483. Leslie and Gardiner, The Roman Empire (see above, n. 6), pp. 141-148. Hoppál, "The Roman Empire” (see above, n. 21), pp. 299-30o. Yu, "China” (see above, n. 21), pp. 5 and 10-17.

78 Hou Hanshu 12: Hill, Jade Gate (see above, n. 4), p. 27 and cf. 289-296.

79 See Édouard Chavannes, "Les pays d'Occident d'après le Wei lio," T'oung pao 6 (1905) pp. 519-571. Leslie and Gardiner, The Roman Empire (see above, n. 6), pp. 65-78. Hill, The Peoples (see above, n. 6), 'About the Text' and 'About the Dating and the Background of the Text'. Hoppál, “The Roman Empire” (see above, n. 21), pp. 268-269.

8o For other (later) ancient Chinese accounts relevant to the Roman Empire and the ancient Mediterranean World see Leslie and Gardiner, The Roman Empire (see above, n. 6), p. 3. 33. 57. 80. Cf. also Hoppál, "The Roman Empire” (see above, n. 21), pp. 268-269.

81 Cf. e.g. Leslie and Gardiner, The Roman Empire (see above, n. 6), pp. 19-31. Hoppál, "The Roman Empire" (see above, n. 21), p. 269 with further bibliography. 
routes undoubtedly played a fundamental role. ${ }^{82}$ The characterization of the Romans in the Hou Hanshu as 'honest in business: they do not have two prices' or the long list of 'products of Da Qin' in the Wei Lüe reflect the importance of long distance trade in transmitting information from the Mediterranean to China. ${ }^{83}$ A particularly complex issue concerns the identification of topographical and geographical features in the ancient Chinese accounts. The main difficulty is that the transcription of foreign place names from Chinese characters and the reconstruction of their phonological values in the Han period requires a highly specialized knowledge of Chinese historical phonology and, apparently, nevertheless often produces highly controversial results. ${ }^{84}$ Moreover, it is not usually taken into account that many places in the Roman East, in particular, had more than one name, and that the Chinese authors may have transcribed pronunciations of place names that (multiple) transmission by non-Greek and non-Latin speakers had significantly distorted.

The matter is clearly important if we want to understand and make use of these texts. The introduction to the chapter on the Roman Empire in the Hou Hanshu might serve as an illustration: 'The Kingdom of Da Qin is also called Lijian. As it is found to the west of the sea, it is also called the Kingdom of Haixi (= 'West of the Sea')'. ${ }^{85}$ Nearly the same statement was also included into the Wei Lüe. ${ }^{86}$ It is perhaps not entirely surprising that the legendary empire of 'Greater China', as a real state, also had other, less mythical names, which derived from existing political or geographical entities. However, there is no consensus, which countries or regions Líjiān and Haixi referred to, and it therefore even remains unclear what parts the term Da Qin exactly denoted. There are various competing theories concerning the derivation and location of

82 This aspect will be discussed in full in Anne Kolb and Michael A. Speidel, "Imperial Rome and China: Contacts and the Collection of Information," in Proceedings of the 22nd International Congress of historical Sciences, 23.-29. August 2015, Jinan, Shandong, China (Cambridge, forthcoming).

83 Hou Hanshu 12: Hill, Jade Gate (see above, n. 4), p. 27. Wie Lüe 12: Hill, The Peoples (see above, n. 6), section 12. For reports of contacts between China and the West (including Rome) from the second century CE onwards see e.g. Graf, "The Roman East" (see above, n. 64), p. 200. Leslie and Gardiner, The Roman Empire (see above, n. 6), pp. 150-162. Hill, Jade Gate (see above, n. 4), pp. 291-296.

84 On the matter in general see esp. Pulleyblank, "The Roman Empire" (see above, n. 21). Hill, Jade Gate (see above, n. 4), pp. xix-xx.

85 Hou Hanshu 11: Hill, Jade Gate (see above, n. 4), p. 23.

86 Wie Lüe 11: Hill, The Peoples (see above, n. 6), section 11: 'The kingdom of Da Qin is also called Lijian. It is west of Anxi (Parthia) and Tiaozhi, and West of the Great Sea'. Cf. also Leslie and Gardiner, The Roman Empire (see above, n. 6), p. 67. 
Lijian, including Hyrcania, Alexandria, Petra, Seleucia, Media, and Rai (ancient Teheran). ${ }^{87}$ Edwin Pulleyblank, a leading expert of Chinese historical phonology, maintained in his review of Donald D. Leslie's and Kenneth H.J. Gardiner's The Roman Empire in Chinese Sources that Lijian was the Han transcription for Hyrcania, the region on the southern shores of the Caspian Sea. ${ }^{8}$ In his opinion, however, the name Lijian was used in ancient Chinese records to refer to the former Seleucid Empire. Later, according to Pulleyblank, at some time after the absorption of the last (i.e. Syrian) remains of the Seleucid kingdom by the Roman Empire 'it was decided at the Han court that Dà Qín corresponded to Lijiān'. Considering that important strands of the over land silk routes led to Zeugma and to Antioch in the Roman provincia Syria, the association of Da Qin with a term for Syria would surely be fitting. ${ }^{89}$ Recently, John E. Hill also maintained that Lijian was a term that referred to former Seleucid territory. ${ }^{90}$ Rather disconcertingly, however, and contrary to Pulleyblank's lengthy argument (which Hill does not refer to in this matter), he claimed that the term Lijian derived from the Greek name of the Seleucid Empire. Notwithstanding, Yu Taishan argued even more recently that Lijian (or Lixuan) referred to the Ptolemaic kingdom of Egypt, whereas John E. Hill (unknown, it seems, to Yu Taishan) rather more convincingly suggested that the term Haixi referred to Egypt. ${ }^{91}$ Consequently, the equation of Da Qin, Lijian and Haixi, as well as other attempts to identify place names in the sections of the ancient Chinese records on Da Qin, has led to a confusing and still ongoing debate, ${ }^{92}$ in which, however, the number of options under discussion does not appear to have

$87 \quad$ Hill, Jade Gate (see above, n. 4), p. 256.

88 Pulleyblank, "The Roman Empire" (see above, n. 21), pp. 73-75. Graf, "The Roman East" (see above, n. 64), p. 203 assumed that 'T'iao-chih is simply an attempt to transcribe the word "Tigris"'. According to Pulleyblank ibid., Tiáozhī was the transcription of Seleukeia, and both (Wū)Chísăn and Zésăn that of Alexandria. Yu, "China" (see above, n. 21), p. 25 (without taking note of Pulleyblank's contribution) argues that Lixuan (i.e. Líjiān) is a contracted transcription of [A]lexan[dria]. Hill, The Peoples, section 15 equates Zésăn with Azania on the coast of East Africa, and Leslie and Gardiner, The Roman Empire (see above, n. 6), pp. 190-191. identify Zésăn with Cyprus.

89 Cf. only the itinerary described in the 'Parthian Stations' of Isidore of Charax: FGH $781=$ Duane W. Roller, "Isidoros of Charax (781)," in Brill's New Jacoby, ed. I. Worthington, Brill Online, December 2013, <http://referenceworks.brillonline.com/entries/brill-s-newjacoby/isidoros-of-charax-781-a781>781 F2.

$90 \quad$ Hill, Jade Gate (see above, n. 4), pp. 256-257 with further bibliography.

91 Yu, "China" (see above, n. 21), pp. 5 and 41-42. Hill, Jade Gate (see above, n. 4), pp. 251-254. Hoppál, "The Roman Empire" (see above, n. 21) refrains from identifying Lijian or Haixi. 
changed much since those established by Friedrich Hirth and his immediate successors. Essentially, the proposed solutions for the meaning of 'Da Qin' are the Roman Empire as a whole, the eastern regions of the Empire (as already suggested by Friedrich Hirth), particularly Syria and Egypt, or, depending on the context of the narrative, either Roman territory or the Imperium Romanum as a whole..$^{93}$

So much confusion and so many contradictory interpretations by specialists of the relevant fields of Sinology might discourage scholars of the ancient Mediterranean world to make use of the ancient Chinese accounts of the far West. Yet there is, perhaps, an approach that could lead to more reliable results. For it seems that what ever the terms Lijian and Haixi may have referred to, they were not fully synonymous with Da Qin but rather designated parts or aspects of it. This is, for instance, implied by statements, recorded in the Hou Hanshu, maintaining that one comes 'into Haixi to reach Da Qin' or that 'in these territories ( $s c$. of Da Qin), there are many precious and marvelous things from Haixi: ${ }^{94}$ Another passage from a different chapter of the Hou Hanshu mentions a group of musicians and magicians in $121 \mathrm{CE}$ who claimed that they were from Haixi, which the Chinese who recorded it identified as Da Qin. ${ }^{95}$ Interestingly, the term Lijian does not recur in the sections on Da Qin of the Hou Hanshu or the Wei Lüe. Haixi is the only concrete geographical aspect of Da Qin these texts single out. It might seem reasonable, therefore, to follow John Hill's suggestion and think of Da Qin as referring to the Roman Empire at large, and Haixi to have been a part of it (perhaps Egypt?).

Other passages, however, seem to add to the confusion. For the Hou Hanshu, commenting on the government of Da Qin, records: 'Their kings are not permanent. They select and appoint the most worthy man. If there are unexpected calamities in the kingdom, such as frequent extraordinary winds or rains, he is unceremoniously rejected and replaced. The one who has been dismissed quietly accepts his demotion, and is not angry'. ${ }^{66}$ The equivalent passage in

93 Leslie and Gardiner, The Roman Empire (see above, n. 6), pp. xxi-xxvi and 232. Hill, Jade Gate (see above, n. 4), pp. 254-256. Hoppál, "The Roman Empire" (see above, n. 21), pp. 269-271. Yu, "China" (see above, n. 21), pp. 1-42.

94 Hou Hanshu 12: Hill, Jade Gate (see above, n. 4), p. 27. Cf. Leslie and Gardiner, The Roman Empire (see above, n. 6), p. 52. Hou Hanshu 10: Hill, Jade Gate (see above, n. 4), p. 23. Cf. Leslie and Gardiner, The Roman Empire (see above, n. 6), p. 47.

95 Leslie and Gardiner, The Roman Empire (see above, n. 6), p. 42. Pulleyblank, "The Roman Empire" (see above, n. 21), p. 75. Hill, Jade Gate (see above, n. 4), p. 291. Cf. Hoppál, "The Roman Empire" (see above, n. 21), p. 270. Yu, "China" (see above, n. 21), p. 22.

96 Hou Hanshu 11: Hill, Jade Gate (see above, n. 4), p. 25. Cf. Leslie and Gardiner, The Roman Empire (see above, n. 6), p. 49. 
the Wei Lüe reads: 'The ruler of this country is not permanent. When disasters result from unusual phenomena, they unceremoniously replace him, installing a virtuous man as king, and release the old king, who does not dare show resentment. ${ }^{97}$ This statement is alternatively thought to refer to the second century CE imperial practice of appointing a successor to the throne by adoption, the Adoptivkaisertum, or to refer to the Republican system of elected consuls, or to be nothing more than a fabulous story of an ideal country far-away ${ }^{98}$ However, other parts of the same passage suggest a completely different solution. In these, the king is said to have regularly left his palace to hear cases, and, according to the Hou Hanshu: 'a porter with a bag has the job of always following the royal carriage. When somebody wants to discuss something with the king, he throws a note into the bag. When the king returns to the palace, he opens the bag, examines the contents, and judges if the plaintiff is right or wrong.99 The parallel passage in the Wei Lüe reads: 'When the king goes out, he always orders a man to follow him holding a leather bag. Anyone who has something to say throws his or her petition into the bag. When he [i.e. the king] returns to the palace, he examines them and determines which are reasonable'.100 The passages in both texts also contain references to governmental archives and to a group of counselors.

It is very tempting to understand these comments as referring to Roman provincial governors rather than to Roman emperors. For it is not difficult to recognize central aspects of a Roman governor's duties: his round trip through his province hearing cases, the well-known system of collecting petitions, preparing responses and making use of archives, as well as discussing matters of state with his consilium. Consequently, the former quote concerning the replacement of kings may perhaps not refer to true kings either, but again to Roman provincial governors. In all events, that would go well with the notion conveyed by the Chinese sources that the country had no permanent ruler but a system (though not entirely understood by the Chinese who recorded it) by which 'worthy' and 'virtuous' men were selected to replace their predecessors.

97 Wie Lüe 11: Hill, The Peoples (see above, n. 6), section 11. Cf. Leslie and Gardiner, The Roman Empire (see above, n. 6), p. 70.

98 Leslie and Gardiner, The Roman Empire (see above, n. 6), p. 49 n. 62 with further bibliography. Hill, The Peoples (see above, n. 6), notes 11.18. Yu, "China" (see above, n. 21), p. 619. Cf. also Hoppál, "The Roman Empire” (see above, n. 21), pp. 276-282 with unconvincing speculations on Rome and Syrian Antioch.

99 Hou Hanshu 11: Hill, Jade Gate (see above, n. 4), p. 25. Cf. Leslie and Gardiner, The Roman Empire (see above, n. 6), p. 48.

100 Wie Lüe 11: Hill, The Peoples (see above, n. 6), section 11. Cf. Leslie and Gardiner, The Roman Empire (see above, n. 6), p. 71. 
One might object that the Chinese texts explicitly refer to the 'king' of Da Qin, not to governors, and therefore seem to be concerned with the Empire at large and with its capital Rome. However, reports of the powers and splendors of Roman provincial governors, not least those of the praefectus Aegypti who resided in the palace of the former Ptolemaic kings and ruled the country in their stead (loco regum), might well have led commentators from the Far East to mistake such governors for local kings. Moreover, the Hou Hanshou and the Wei Luë claim that Da Qin had established several tens of minor 'dependent kingdoms', which might be understood as a reference to the Roman Empire's provinces. ${ }^{101}$ If correct, some details of Roman provincial administration must indeed have reached China during the first two centuries CE. However, we must presumably admit that Chinese knowledge of the Roman Empire (Da Qin) was defective and largely restricted to information from Egypt (Haixi?) and Rome's other eastern provinces.

Finally, some information included in the sections on Da Qin seems to have had Chinese rather than Roman origins. For at least in one instance it appears that cultural and administrative realities of the ancient Chinese Empire contaminated the historical accounts of the Roman Empire. Thus, knowledge of local Chinese institutions appears to have affected the short descriptions of the Roman imperial system of transport and communication. Both the Hou Hanshu and the Wei Lüe refer in surprising detail to the rest stops of this system, to the distances between them and to their appearance: 'At intervals they have established postal relays, which are all plastered and whitewashed... Each ten li $(4.2 \mathrm{~km})$ there is a postal stage, and each thirty $l i(12.5 \mathrm{~km})$ a postal station. ${ }^{102}$ The purpose of this Roman institution was also recorded by the Chinese: 'Relay stations were established in strategic positions allowing orders to travel quickly

101 Splendors: Tac., Hist. 1,11,1. Strabo 17,1,12. For a recent discussion and further bibliography cf. e.g. Andrea Jördens, Statthalterliche Verwaltung in der römischen Kaiserzeit. Studien zum praefectus Aegypti (Stuttgart, 2009) 11-15. Anne-Valérie Pont, "Rituels civiques (apantêsis et acclamations) et gouverneurs à l'époque romaine en Asie Mineure," in: Ritual Dynamics and Religious Change in the Roman Empire, ed. O. Hekster, S. Schmidt-Hofner, C. Witschel (Leiden, 2009), pp. 185-211. Dependent kingdoms (or provinces?): Hou Hanshu 11: Hill, Jade Gate (see above, n. 4), p. 23. Cf. Leslie and Gardiner, The Roman Empire (see above, n. 6), p. 47. Wei Luë 11 (the reference here is to dependent kings): Hill, The Peoples (see above, n. 6), section 11, and Leslie and Gardiner, The Roman Empire (see above, n. 6), p. 71. Hou Hanshu 11 and 12: Hill, Jade Gate (see above, n. 4), p. 26 and 27. Cf. Leslie and Gardiner, The Roman Empire (see above, n. 6), pp. 47 and 52. For the respective passage in the Wei Lüe (11) see Hill, The Peoples (see above, n. 6), section 11, and Leslie and Gardiner, The Roman Empire (see above, n. 6), p. 70. Cf. also Hoppál, "The Roman Empire" (see above, n. 21 ), p. 282. 
between the main postal stations at all seasons.'103 These statements have been understood to refer to the vehiculatio or cursus publicus of the Roman Empire, as it was indeed among the purposes of this Roman institution to transmit official communications quickly, and as the description of its infrastructure in the Chinese accounts appear to be accurate enough. ${ }^{104}$

However, distances of 10 li $(4.2 \mathrm{~km})$ between postal stages and thirty li (12.5 $\mathrm{km}$ ) between the larger postal stations are not confirmed by Roman sources. Although Roman itineraries do list small and large stopping places, they are recorded at intervals of 6-12 miles (c. 9-18 km) and 25 miles ( $37 \mathrm{~km})$, which correspond to around half a day's and a whole day's journey by foot respectively. That amounts to two or three times the distance indicated by the Chinese sources. ${ }^{105}$ In particular, the very short distances of $4.2 \mathrm{~km}$ were not in use in the Roman Empire. Perhaps there was confusion between postal stations and local inns, which probably lay at rather close intervals in the vicinity of cities. Yet, another perhaps more plausible solution might be that the Chinese authors' knowledge of their own postal system contaminated their account of Da Qin, for these texts insist that the Roman and Chinese postal systems were nearly identical: 'They have ... postal stations just as we have them in China'.106 It is particularly suggestive, therefore, that Chinese sources from the Qin Empire mention short distances of 2.6 miles between the postal stops, which precisely equals the distance of $10 \mathrm{li}(4.2 \mathrm{~km})$ as recorded in the Hou Hanshu and the Wei Lüe. ${ }^{107}$ The perceived identity of these important institutions both in China and in 'Greater China' (Da Qin / Rome) may therefore have encouraged the Chinese authors and compilers to insert additional "information".108 It is therefore perhaps not to be excluded that the ancient Chinese accounts of Da Qin contain more such supplemented information that originated from knowledge of Chinese institutions.

\footnotetext{
103 Hou Hanshu 28: Hill, Jade Gate (see above, n. 4), p. 55.

104 On the subject in general see Anne Kolb, Transport und Nachrichtentransfer im Römischen Reich, (Berlin, 2000).

105 Kolb, Transport, pp. 212-213.

106 Wei Lüe 11: Hill, The Peoples (see above, n. 6), section 11. Leslie and Gardiner, The Roman Empire (see above, n. 6), p. 70. See also Hirt, China (see above, n. 6), p. 44 (Chin-shu) and 70. Leslie and Gardiner, The Roman Empire (see above, n. 6), p. 81.

107 Chun-shu Chang, The Rise of the Chinese Empire, vol. 1 (Ann Arbor, 2007), p. 54, who also mentions intervals of 5,2 miles $(8.4 \mathrm{~km})$.

108 For the postal service of ancient China see Peter Olbricht, Das Postwesen in China unter der Mongolenherrschaft im 13. und 14. Jahrhundert (Wiesbaden, 1954), p. 36. Michael Loewe, The Government of the Qin and Han Empires 221 BCE-220 CE (Indianapolis, 2006), pp. 106-118.
} 
Perhaps the most significant notion that emerges from this admittedly very cursory overview of disparate evidence is the enormous geographical distribution of detailed information (however accurate) of the Roman Empire throughout the ancient world at large. ${ }^{109}$ Evidently, this was a consequence of global connectivity, long distance trade, and the impressive reputation of the Imperium Romanum and its rulers. However, making further use of the surviving evidence in most cases requires close collaboration between scholars of the Classical World and the respective specialists of other ancient civilizations. Such collaboration, we believe, promises rewarding results for all fields involved and would significantly contribute to the complex contemporary outside perception of the Roman Empire and its impact on the ancient world at large.

109 Cf. also the overview of relevant evidence in McLaughlin, Rome (see above, n. 35), pp. 16-21. 